\title{
Nutritional status of school going children (7-9 years) in rural area of Bhilwara district (Rajasthan)
}

\author{
GITIKA SHARMA AND SARLA LAKHAWAT
}

Received: 01.12.2015; Revised: 13.05.2016; Accepted: 24.05.2016

See end of the paper for authors' affiliations

\section{GITIKA SHARMA}

Department of Food and Nutrition,

Maharana Pratap University of

Agriculture and Technology,

College of Home Science, UDAIPUR

(RAJASTHAN) INDIA

Email : gitikasharma718@gmail.

com

\begin{abstract}
The present study was conducted with an objective to assess nutritional status of school going children. The study was conducted in village Hurda of Hurdapanchayatsamiti of Bhilwara district of Rajasthan. Total 120 school going children (15 girls and 15 boys from each school) were selected. Nutritional status of the subjects was assessed by using anthropometric measurements (height and weight), clinical assessment and dietary recall method. All respondents were vegetarian. The height and weight of respondents was lower than reference value. Severely wasted $(44.43 \%)$, Severely stunted (32.2) according to Waterlow classification. Gomez classification revealed (60\%) respondent's was severely malnourished. According to BMI for age z- score severely undernourished was found 33.33 per cent. In Clinical assessment of respondent's revealed equal number of respondents was in normal and poor appearance $(41.66 \%)$. Diffused pigmentation in children were $(25 \%)$, lack of luster were $(16.66 \%)$, Pale conjunctiva were (23.33), Cheilosis (19.16). Dietary intake of respondents was substantially inadequate $(<50 \%)$ in all food groups whereas intake of sugar was marginally adequate $(83 \%)$ dietary intake was lower than recommended dietary intake (RDI). The mean nutrient intake was significantly lower than recommended dietary allowances .Intake of protein of respondents was 81 per cent of RDA.
\end{abstract}

GEY WORDS: Recommended dietary allowances (RDA), Recommended dietary intake (RDI)

- HOW TO CITE THIS PAPER : Sharma, Gitika and Lakhawat, Sarla (2016). Nutritional status of school going children (7-9 years) in rural area of Bhilwara district (Rajasthan). Asian J. Home Sci., 11 (1) : 220-225, DOI: 10.15740/HAS/AJHS/11.1/220-225. 